\title{
RANKING PRODUCT SYSTEMS BASED ON UNCERTAIN LIFE CYCLE SUSTAINABILITY ASSESSMENT: A STOCHASTIC MULTIPLE CRITERIA DECISION ANALYSIS APPROACH
}

\author{
RANQUEAMENTO DE SISTEMAS DE PRODUTOS \\ BASEADO NA AVALIAÇÃO DA SUSTENTABILIDADE \\ DO CICLO DE VIDA: TOMADA DE DECISÃO \\ ESTOCÁSTICA BASEADA EM MÚLTIPLOS CRITÉRIOS
}

\author{
Breno Barros Telles do Carmo ${ }^{1}$ \\ Manuele Margni² \\ Pierre Baptiste ${ }^{2}$ \\ 1 Federal University of Smiarid Region, Engineering Centre. Mossoró, Rio Grande do Norte, Brazil \\ 2 École Polytechnique de Montréal, Montréal, Québec, Canada
}

\begin{abstract}
Purpose - Life cycle sustainability assessment (LCSA) provides useful and comprehensive information on product system performance. However, it poses several challenges for decision-making process due to (i) multidimensional indicators, (ii) conflicting objectives and (iii) uncertainty associated with the performance assessment. This research proposes an approach able to account uncertain life cycle sustainability performances through multiple criteria decision analysis (MCDA) process to support decision-making.

Design/methodology/approach - Our method is structured in three phases: i) assessing the uncertainty of LCSA performances, ii) propagating LCSA uncertainty into MCDA methods and iii) interpreting the stochastic results. The approach is applied on an illustrative case study, ranking four alternatives to biodiesel supply.

Findings -The recommendation generated by this approach provides an information about the confidence the decision maker can have in a given result (ranking of solutions) under the form of a probability, providing a better knowledge of the risk (in this case due to the uncertainty of the preferred solution). As such, stochastic results, if appropriately interpreted, provide a measure of the robustness of the rankings generated by MCDA methods, overcoming the limitation of the overconfidence of deterministic rankings.

Originality/value - The fundamental contributions of this paper are to (i) integrate LCSA uncertainty into decision-making processes through MCDA approach; (ii) provide a sensitivity analysis about the MCDA method choice, (iii) support decision-makers' preference choices through a transparent elicitation process and (iv) provide a practical decision-making platform that accounts simultaneously uncertain LCSA performances with stakeholders' value judgments.

Keywords - Life cycle sustainability assessment; Multiple criteria decision analysis; Uncertainty; Decision-making.
\end{abstract}




\section{RESUMO}

Propósito - A avaliação de sustentabilidade do ciclo de vida (LCSA) fornece informações úteis e abrangentes sobre o desempenho de um sistema de produtos. Entretanto, existem alguns desafios associado ao processo de tomada de decisão envolvendo esses resultados: (i) indicadores multidimensionais, (ii) objetivos conflitantes e (iii) incerteza associada à avaliação de desempenho. Esta pesquisa propõe uma abordagem que considera a incerteza do desempenho em termos de sustentabilidade do ciclo de vida através do processo de análise de decisão baseado em múltiplos critérios (MCDA) para apoiar a tomada de decisão.

Metodologia - Nosso método está estruturado em três fases: i) avaliação da incerteza do desempenho obtido por meio da LCSA, ii) propagação da incerteza da LCSA nos métodos MCDA e iii) interpretação dos resultados estocásticos. A abordagem foi aplicada em um estudo de caso ilustrativo, classificando quatro alternativas de fornecimento de biodiesel.

Resultados - A recomendação gerada por esta abordagem fornece uma informação sobre a confiança que o tomador de decisão pode ter em um determinado resultado (classificação de soluções) sob a forma de uma probabilidade, proporcionando um melhor conhecimento do risco (neste caso devido à incerteza da solução preferida). Assim, os resultados estocásticos, se interpretados de forma adequada, fornecem uma medida da robustez dos rankings gerados pelos métodos MCDA, superando a limitação do excesso de confiança dos rankings determinísticos.

Originalidade - As contribuições fundamentais deste artigo são (i) integrar a incerteza da LCSA nos processos de tomada de decisão por meio da abordagem MCDA; (ii) fornecer uma análise de sensibilidade sobre a escolha do método MCDA, (iii) apoiar as escolhas de preferência dos tomadores de decisão por meio de um processo de elicitação transparente e (iv) fornecer uma plataforma de tomada de decisão prática que contabiliza simultaneamente os desempenhos das performances LCSA incertas com julgamentos de valor das partes interessadas.

Palavras-chave - Avaliação da sustentabilidade do ciclo de vida; Decisão baseada em múltiplos critérios; Incerteza; Tomada de decisão.

\section{INTRODUCTION}

Currently, decision-making in business context cannot be based only on economic efficiency perspective. Environmental and social issues expanded prominence in recent decades. These three pillars are the basis of sustainability concept (Yanarella, et al., 2009; Pope et al., 2004). Zamagni et al. (2013) note most companies include the concept of sustainability in their mission, However, how to operationalize this concept realistically and how use this information in decision-making processes remains a gap to be fulfilled (Finkbeiner et al., 2010). For example, making decisions through a sustainable perspective implies subjective preferences and value choices because there is rarely an alternative presenting the best performances in all three sustainability dimensions and their respective indicators.

Pope et al. (2004) suggest the use of term sustainability assessment for determining whether or not an alternative is sustainable. This kind of assessment is a comprehensive source of information to support decision-making processes toward sustainable production and consumption (Keller et al., 2015; Traverso et al., 2012). However, Pope et al. (2004) remark the practical difficulty of integrating the three pillars' assessments when promoting sustainability and argue that these studies tend to limit themselves to measure whether or not an alternative represent a positive or negative impact for sustainability.

Life cycle sustainability assessment (LCSA) refers to environmental, social and economic evaluations of product systems from a life cycle perspective (Zamagni et al., 2013). These three dimensions of sustainability may be seen as three different perspectives of the same product system (Heijungs et al., 2010).

Different types of indicators are used to measure the sustainability of a product system 
considering a life cycle perspective. Endpoint damage, such as human health, ecosystem quality, resources and global warming (considering Impact 2002+ method, for example) are used to evaluate environmental performance. Stakeholder dimensions, such as workers, society, local community, supply chain actors and consumers (considering social life cycle assessment - SLCA - type I approach, for example) are used to evaluate social performance, as discussed by Carmo et al. (2017). Finally, life cycle costing (LCC) or the purchase cost can be used to evaluate economic performance. Klöpffer and Ciroth (2011) argue also that LCSA use also depends on the improvement of life cycle methods, especially for LCC and SLCA, due to the lack of internationally standardized processes for both, despite the UNEP/SETAC guidelines.

As such, LCSA results could be too disaggregated, uncertain and difficult to be understood and interpreted by decision-makers (Traverso et al., 2012). Using these indicators in combination into a decision-making process, however, is a challenge because the likelihood of a specific product system presenting the best results for all indicators is rare.

Halog and Manik (2011) highlight the characteristics increasing the complexity of the LCSA results use in decision-making processes: (i) multidimensional indicators (each indicator is expressed in different units), (ii) conflicting objectives (it is impossible to maximize performances for all indicators) and (iii) uncertainty associated with the performance assessment.

Concerning environmental dimension, Cucurachi et al. (2017) remark that current practices of environmental life cycle assessment (LCA) still lack connection to structured approaches for decision making. Henriksson et al. (2015) argue that uncertainties surrounding values necessitate more sophisticated ways of communicating environmental performances. Both issues are similar to LCSA and must be addressed in order to improve LCSA as an analytic tool.

While aggregating LCSA results is useful for decision-making, Bengtson (2001) argue that aggregated results may be regarded as a simplification, and additional knowledge is required to understand the meaning of this measure. Rowley et al. (2012) argue that the use of different methodological approaches to weighting and aggregation can introduce subjectivity and uncertainty. Thus, a transparent structured process is necessary when carrying out the process. Martín-Gamboa et al. (2017) identified the lack of methodological frameworks able to integrate reliable sustainability indicators, such as LCSA, and decision-makers' preferences into decision-making processes. As such, the objective of this paper aims to fulfill this gap, proposing an approach that propagates uncertain life cycle sustainability assessment into Multiple Criteria Decision Analysis (MCDA) methods to support sustainable decision-making in company context.

\section{MULTIPLE CRITERIA DECISION ANALYSIS AS SUSTAINA- BLE DECISION-MAKING TOOL}

\subsection{Multiple Criteria Decision Analysis main concepts}

Shäarlig (1985) describes three approaches able to address decision-making problems when multiple criteria are considered: clinical, objective and compromise approaches. The first one (clinical approach) aims to solve problems by establishing only a sufficient solution (subjective and empiric), leading to a not efficiency solution. The second approach (objective) solves the problem optimally and is based on measures. However, the optimal solution is implicitly defined based on a single criterion and the complexity of the decision is not captured. Finally, the third approach (compromise) seeks to find an ideal solution, which is not necessarily optimal in all criteria, but represents the compromise solution according to the value judgment of decision makers. 
The MCDA approach relies on objectives and the value judgment of decision-makers (Roy, 2005). Shärlig (1985) proposes four major steps to conduct an MCDA study: (i) setting out a list of hypothetical alternatives, (ii) defining the criteria to assess the alternatives, (iii) assessing the performance of the alternatives in each criterion and (iv) aggregating the results to obtain the compromise solution.

There are numerous MCDA methods. Guitouni and Martel (1998) classify them into three classes: elementary, single synthesizing criterion and outranking methods.

Elementary methods are the least sophisticated and there is no standard technique. The most common methods in this group are weighted sum, lexicographic method, conjunctive method, disjunctive method and maxmin method (Guitouni and Martel, 1999).

Single synthesizing criterion methods combine the performances into a single score. However, aggregating all the criteria into a single score leads to nuance loss. Indeed, the aggregation generates performance compensation among criteria performances (Shärlig, 1985). The most common methods in this class include the technique to order by similarity to ideal solution (Topsis) and the analytic hierarchy process (AHP) (Guitouni and Martel, 1998), among others.

Outranking methods take into account the aspects of intransitivity and incomparability when modeling decision problems and are based on binary outranking relations between all pairwise of alternatives (Chai et al., 2013). The most common methods in this class are preference ranking organization method for enrichment evaluation (Prométhée) and elimination and choice expressing reality (Electre) (Guitouni and Martel, 1998).

The choice of MCDA method depends on the type of problem that it is able to solve. Alfa problems consider separating alternatives into two subsets: acceptable and reject. Beta problems consider separating alternatives into subsets with comparable performances. Finally, gamma problems consider ranking alternatives from the most to the least efficient. Box 1 presents a brief description of the MCDA methods applied in our research without discussing them in detail since this is not the goal of this paper and scientific literature on the topic is widely available. All these methods rank alternatives (gamma problem).

Initially, the MCDA approach was not designed to deal with uncertain data. However, all decision-making problems involving natural systems inherit uncertainty associated with data and models. Research addressing uncertainty in MCDA is relatively common. Some scientific papers (Goumas and Lygerou, 2000; Yang and Wang, 2011; Amiri et al., 2008; Vahdani et al., 2010; Sayyadi and Makui, 2012; Balali et al., 2014; Le Téno and Mareschal, 1998; Qureshi et al., 2007; Zhang and Achari, 2010; Hyde et al., 2003; Marinoni, 2005; Qiao et al., 2019) address MCDA problems in terms of uncertainty. Three approaches are commonly used to address the uncertainty in multiple criteria decision analysis by fuzzy logic, interval numbers and Monte Carlo simulation techniques.

Two research papers applied fuzzy logic to include uncertain data in MCDA methods (Goumas and Lygerou, 2000; Yang and Wang, 2011). Some addressed the uncertainty problem through interval numbers (Amiri et al., 2008; Vahdani et al., 2010; Sayyadi and Makui, 2012; Balali et al., 2014; Le Téno and Mareschal, 1998; Qureshi et al., 2007; Zhang and Achari, 2010; Qiao et al., 2019). Finally, two publications addressed uncertainty in MCDA methods by Monte Carlo simulation (Hyde et al., 2003; Marinoni, 2005), a technique that is widely used to calculate the uncertainty associated with life cycle assessment results.

\subsection{Integrating LCSA into decision-making problems through MCDA}

In LCSA domain, due to the multidimensional characteristic, the compromise approach is indicated when addressing this kind of decision-making problem. The main advantage is its ability 
Box 1. Description of MCDA methods discussed in this paper

\begin{tabular}{|c|c|c|c|}
\hline $\begin{array}{l}\text { Class of } \\
\text { MCDA } \\
\text { method }\end{array}$ & $\begin{array}{l}\text { MCDA } \\
\text { method }\end{array}$ & Description & General procedure \\
\hline Elementary & $\begin{array}{l}\text { Weighted } \\
\text { sum }\end{array}$ & $\begin{array}{l}\text { Overall performance is } \\
\text { obtained by the weighted } \\
\text { sum of the normalized } \\
\text { evaluations in all criteria. } \\
\text { These results are used as } \\
\text { data to rank the } \\
\text { alternatives (Guitouni and } \\
\text { Martel, 1998). }\end{array}$ & $\begin{array}{l}1^{\text {st }} \text { step - Normalize the performances of the alternatives for each } \\
\text { criterion. } \\
2^{\text {nd }} \text { step - Calculate weighted sum: } \\
P_{a_{i}}=\sum_{j \in J} r_{i j} * w_{j} ; \quad \forall i \in A \\
\text { Where, } \\
\text { A:set of alternatives; l: set of criteria; } \\
r_{1 j}: \text { normalized performance of alternative } i \text { at criterion } j ; \\
w_{j}: \text { weight attributed to criterion } j \\
2^{\text {nd }} \text { step - Rank alternatives considering weighted sum result. }\end{array}$ \\
\hline \multirow[t]{2}{*}{$\begin{array}{l}\text { Single } \\
\text { synthesizing } \\
\text { criterion }\end{array}$} & TOPSIS & $\begin{array}{l}\text { The alternative is chosen } \\
\text { based on the shorter } \\
\text { distance from the ideal } \\
\text { solution and the longer } \\
\text { distance from the negative } \\
\text { ideal solution, considering } \\
\text { each single criterion } \\
\text { (Qureshi et al. 2007). }\end{array}$ & 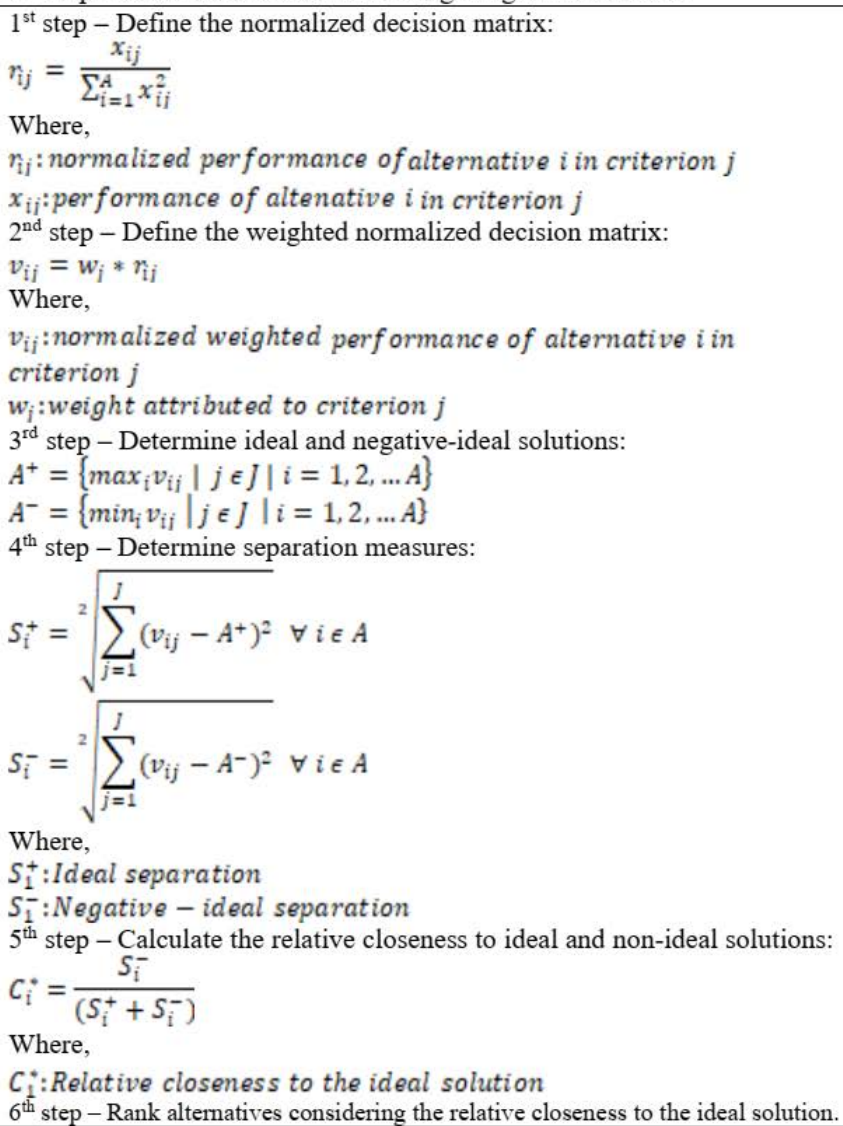 \\
\hline & $\begin{array}{c}\text { Analytic } \\
\text { hierarchy } \\
\text { process } \\
\text { (AHP) }\end{array}$ & $\begin{array}{l}\text { The process is based on } \\
\text { pairwise comparisons of } \\
\text { alternatives considering a } \\
\text { semantic scale. A single } \\
\text { score is calculated for all } \\
\text { alternatives in all criteria } \\
\text { to provide a complete } \\
\text { ranking (Saaty, 2005). }\end{array}$ & 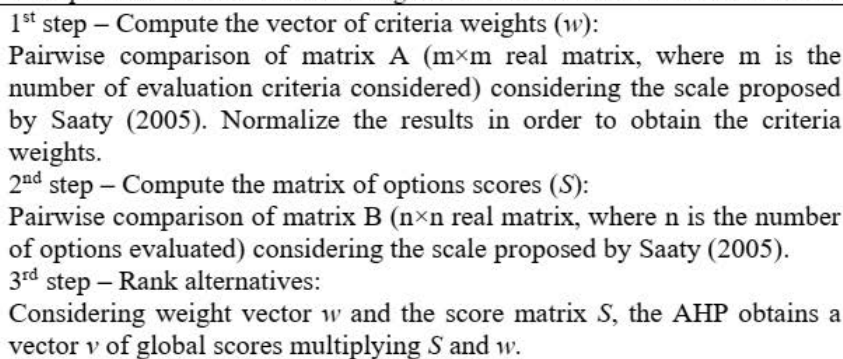 \\
\hline
\end{tabular}


Box 1. continuation

\begin{tabular}{|c|c|c|c|}
\hline Outranking & $\begin{array}{c}\text { Prométhée } \\
\text { II }\end{array}$ & $\begin{array}{l}\text { This method is based on a } \\
\text { pairwise comparison of } \\
\text { alternatives in all criteria } \\
\text { considering the } \\
\text { discrimination thresholds } \\
\text { of indifference and } \\
\text { preference. The } \\
\text { aggregated results are the } \\
\text { basis to establish the } \\
\text { outranking of one } \\
\text { alternative over another. } \\
\text { This method proposes a set } \\
\text { of preference functions to } \\
\text { model the decision- } \\
\text { makers' preference } \\
\text { systems (Brans and } \\
\text { Mareschal, 2005; } \\
\text { Marinoni, 2005; Le Téno } \\
\text { and Mareschal, 1998; } \\
\text { Goumas and Lygerou, } \\
\text { 2000; Hyde et al., 2003). }\end{array}$ & 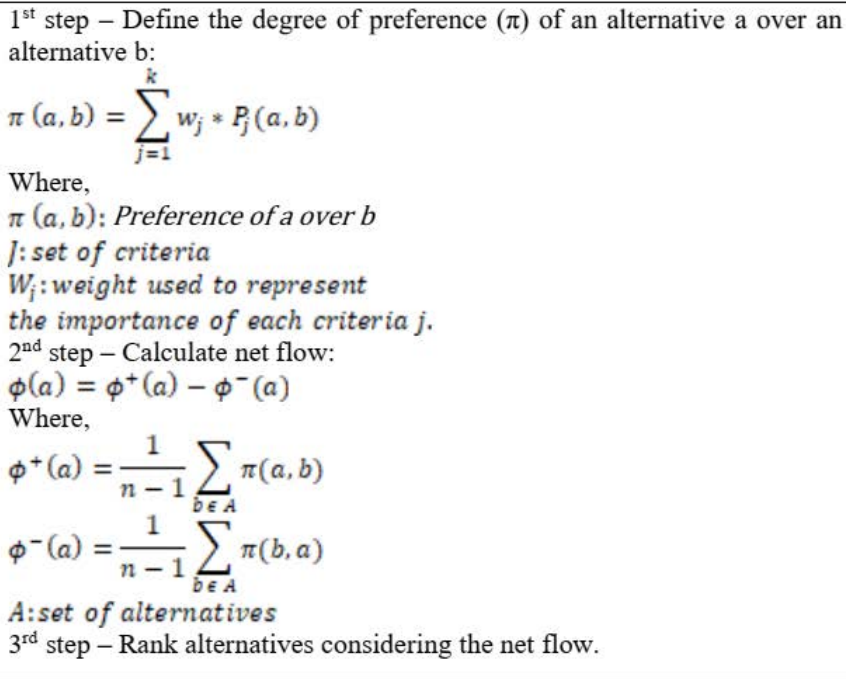 \\
\hline
\end{tabular}

to consider a relatively large number of criteria when deciding, in contrast to single-criterion-based models (Shärlig, 1985). Furthermore, MCDA methods are able to address conflicting objectives and uncertain performances, intrinsic characteristics of LCSA results (Halog and Manik, 2011). The adoption of these kind of methods to support decision-making problems can provide more-rational decision support in terms of accounting for the positive and negative aspects of products/services (Kalbar et al., 2017).

Martín-Gamboa et al. (2017) argue in favor of robust quantitative methods to interpret jointly the multiple criteria and decision-makers' preferences, such as MCDA approach. The same conclusion was obtained by Finkbeiner et al. (2010), Vinyes et al (2013), Lora et al. (2011), Bachman (2013) and Kalbar et al. (2017), who argue the use of MCDA methods to support decision-making involving LCSA results. Laurin et al. (2016) also note the use of this approach when comparing product systems, enhancing the LCA domain through trade-off analysis. Finally, Onat et al. (2016) argue that MCDA methods are useful in order to strengthen the life cycle approach as a tool.

We found few scientific papers considering MCDA methods in life cycle assessment research (Vinyes et al (2013); Keller et al. (2015); Myllyviita et al., 2012 and Hanandeh, El-Zein, 2010 and Traverso et al., 2012). Work by Vinyes et al (2013) and Keller et al. (2015) rely on simplified aggregation procedures and neglect uncertainty when selecting a product system based on LCSA results among a set of alternatives. Myllyviita et al. (2012) used the MCDA approach to identify and weight relevant impact categories when assessing the environmental impacts of biomass production. Traverso et al. (2012) provide a tool to compare product systems based on LCSA performances. However, they do not define a procedure to establish the weighting factors and they do not consider the uncertainty associated to LCSA results. Finally, Hanandeh and El-Zein, 2010 adapted the Electre III method to accommodate the uncertainty associated with preference data as weighting factors when choosing among alternatives based on LCA performance. In a larger sustainability perspective (not restrictive to LCSA), Nie et al. (2018) proposed an interesting decision support framework including sustainability indicators not following a life cycle approach and not including uncertainty characteristic on their model.

We also identified the research conducted by Prado-Lopez et al. (2014) addressing the 
problem of environmental LCA uncertainty when making decisions. However, the authors only consider the environmental dimension and not conducted a sensitivity analysis concerning the different approaches that can be used to aggregate results when supporting decisions through MCDA methods. They use only the outranking concept without analyse other approaches. Sohn et al. (2017) implemented Topsis method to support environmental decision-making problem. However, they not included uncertainty analysis and tested other MCDA methods. Kalbar et al. (2016) argue in favor of the uncertainty analysis inclusion in order to support the interpretation process by in LCA domain. Both issues are common to LCSA.

As such, none research conducted an analysis including the issues pertaining to uncertain LCSA performances when supporting decision-making processes. Thus, the most relevant problem identified on these researches is the uncertainty neglect when supporting decision-making through life cycle assessments.

\section{METHODOLOGY}

\subsection{Approach to make decisions based on uncertain LCSA results}

Figure 1 presents a general overview of the proposed approach to support decisions based on uncertain LCSA results by multiple criteria decision analysis (MCDA). It is important to remark that two different input are necessary in order to aggregate performances and provide the product systems ranking: (i) product systems profiles (LCSA performances) and (ii) mandatory parameters (weighting sets and preference thresholds - provided by decision-makers through a survey realized with decision-makers - available at supporting information). These results are used as entry of the performance matrix of MCDA methods.

This information is used by each MCDA method in order to generate the recommendation. We selected four multiple criteria methods. The first one, Weighted Sum, is an elementary method

Figure 1. Approach to support decision-making under uncertain life cycle sustainability assessment (LCSA) results by multiple criteria decision analysis (MCDA) methods

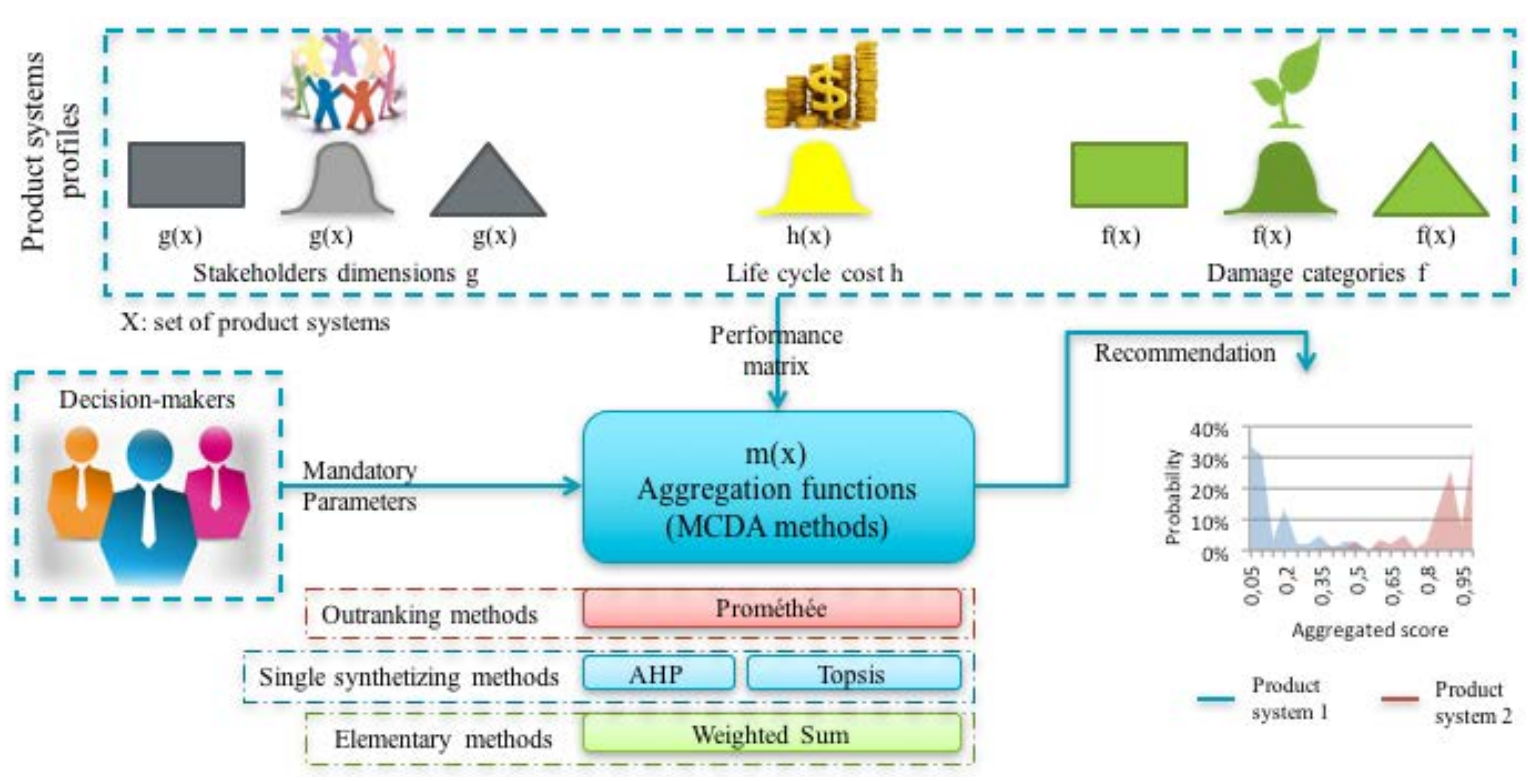


that includes compensation characteristic to rank the alternatives (a good performance in a single criterion balance another criterion presenting a bad performance). The second technique, Topsis, is a method that rank alternatives based on their performance's distance to "the ideal solution" - the best result obtained by any alternative into each criterion. The third technique, Analytic Hierarchy Process, provide the rank based on a set of pairwise comparison of alternatives in each criterion bases on a semantic scale. Finally, the last technique applied was Promethée II, an outranking method considering the aspects of intransitivity and incomparability when modeling decision problems. All of these methods are widespread in scientific literature and the purpose of using different types of techniques is to provide a sensitivity analysis about the MCDA method choice.

Figure 2 presents the phases considered to implement our framework: (i) assessing product system performance by life cycle approach; (ii) propagating LCSA uncertainty into MCDA methods and (iii) interpreting the stochastic results.

\subsubsection{Assessing product system performance}

The product systems are modeled based on life cycle phases to obtain the performances over the three sustainability dimensions. The sustainability performance assessment relies on social life cycle assessment (SLCA), environmental life cycle assessment (ELCA) and purchase cost.

LCSA inherits uncertainty. Clavreul et al. (2013) remark two distinct nature of uncertainty:

Figure 2. Framework used to support sustainable decision-making through LCSA results and MCDA approach

\section{Phase I: Assessing product system performance}

- Product systems modeling;

- Sustainability assessment:

- Environmental assessment $\longrightarrow$ Impact 2002+

- Social performance assessment $\rightarrow$ Type I SLCA

- Economic profile $\longrightarrow$ Purchase cost (\$)

- Uncertain performance generation by Monte Carlo simulation.

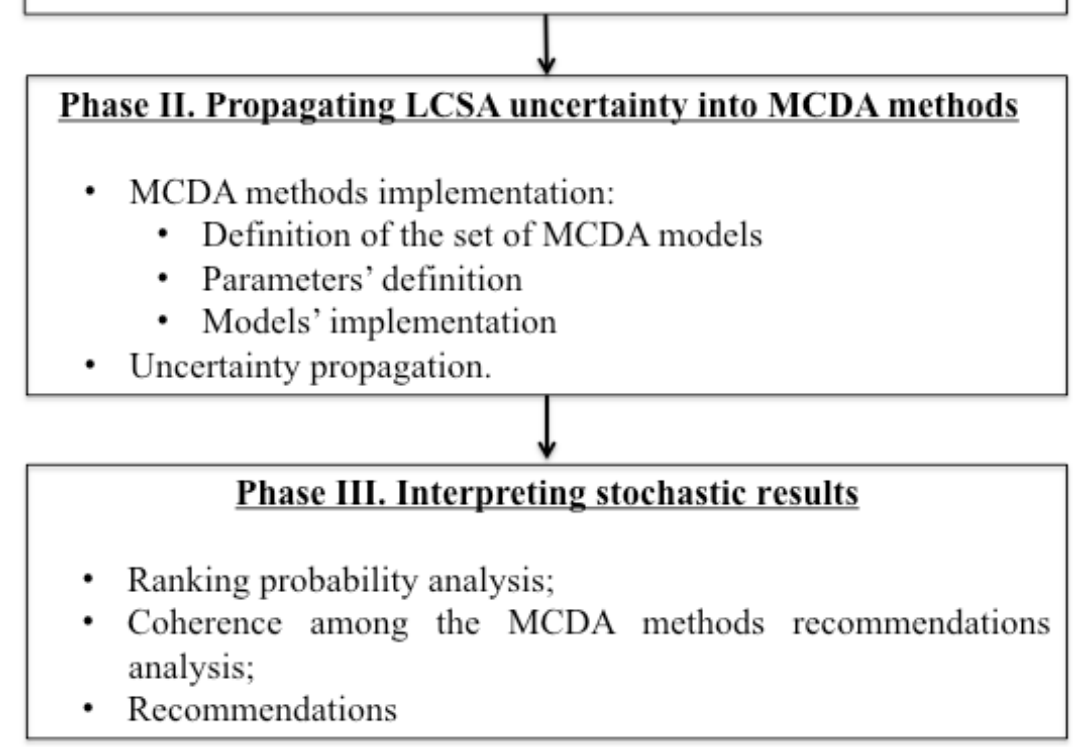


truly stochastic uncertainty, which refers to variability of data and epistemic uncertainty, related to lack of knowledge. We consider the stochastic uncertainty of the environmental dimension, i.e. the uncertainty associated to the life cycle inventory from Ecoinvent database. This database includes uncertainty factors for most of its values. The uncertainty of the characterization factors for the environmental impact assessment (used to convert emissions into impact scores) and the hours of work used to calculate social impacts and the prices used for economic evaluation were not considered (epistemic uncertainty). Clavreul et al. (2013) defend Monte Carlo simulation as the most common method used to propagate stochastic uncertainty in life cycle approach. As such, the uncertain performances of the environmental and social dimensions were calculated using Monte Carlo simulation technique through 1000 simulations, as suggested by Marinoni (2005).

The environmental performances of the four product systems were calculated based on ecoinvent v.03 (Wernet et al., 2016) datasets for feedstock production, transport, biodiesel production and storage scaled to the functional unit and characterized with the IMPACT 2002+ method (Jolliet et al., 2003) for the human health, ecosystem quality, climate change and resources damage categories. We considered the SimaPro model developed by Fagnen et al. (2010) to calculate the environmental impacts, and SimaPro v8.2 was used to compute the results and perform Monte Carlo simulation. For environmental dimension, the model and database constitute the sources of uncertainty.

Social performance is calculated for three stakeholder dimensions: workers, society and local community. For each dimension, subcategory indicators were defined based on the 31 indicators proposed by UNEP (UNEP, 2013), and type I SLCA was used to calculate the social impacts, considering the framework proposed by Sanchez Ramirez (2014) and adapted by Carmo et al. (2017) and the scoring and weighting methods proposed by Carmo et al. (2017). Details on the modeling choices and calculations are provided in Carmo et al. (2017). In this case, the uncertainty relies on scoring factors used to translate the qualitative scales of the subcategory indicators into cardinal scales and weighting factors (both stochastic uncertainty) to aggregate the performances by stakeholder dimension.

\subsubsection{Propagating LCSA uncertainty into MCDA methods}

We considered the gamma problem perspective to rank product systems. To do so, we selected four methods pertaining to the three classes of MCDA methods considering (i) their occurrence in scientific literature, (ii) their ease of understanding by decision-makers and (iii) the accessibility of the method (i.e. ease of implementation without a specific software package). The four MCDA methods were implemented in Microsoft Excel by VBA (Visual Basic for Applications) taking into account calibration parameters and sustainability profiles (i.e. social, environmental and cost performances) of the four product systems as a starting point. The procedure used to apply these methods is provided in Box 1.

Each method requires different mandatory calibration parameters, determined based on the value judgment of decision-makers, as presented in Box 2 . We use the direct elicitation ${ }^{1}$ approach to obtain these parameters through questionnaires and interviews.

\footnotetext{
${ }^{1}$ Elicitation aims explaining decision-makers preferences through a model to represent them. Direct elicitation is based on interaction between MCDA analyst and decision-maker in order to estimate numerical values of the preferential parameters, such as weighting factors and preference thresholds. (Mousseau, 2003)
} 
Box 2. Mandatory calibration parameters for each MCDA method

\begin{tabular}{|c|l|}
\hline MCDA methods & \multicolumn{1}{c|}{ Mandatory calibration parameter } \\
\hline $\begin{array}{c}\text { Weighted sum } \\
\text { TOPSIS }\end{array}$ & - Indicator weights \\
\hline $\begin{array}{c}\text { Analytic hierarchy } \\
\text { process - AHP }\end{array}$ & - Indicator weights \\
\hline Pcale proposed by Saaty (2005) into concrete scale \\
\hline Prométhée II & - Indicator weights \\
& - Indifference and preference thresholds \\
\hline
\end{tabular}

We considered two hierarchy levels to establish weights, as defined by Finkbeiner et al. (2010) and Vinyes et al. (2013): lower level (weights for stakeholder dimensions, damage categories and purchase cost) and higher level (economic, social and environmental dimensions). The weights for the final criteria were calculated by multiplying the weights of the sustainability dimensions (economic, environmental and social) by the weights of the respective indicators (human health, ecosystem quality, resources and climate change for environmental dimension; workers, society and local community for social dimension; purchase cost for economic dimension).

There is no universally accepted weighting method (Laurin et al., 2016). However, we observed three approaches largely used in scientific literature to define the weights: pairwise comparison, criteria preference order assignment and points allocation. The pairwise comparison is more precise but is also more sophisticated and less easily understood by decision-makers. It is currently used in the AHP method (Saaty, 2005). The criteria preference order assignment, represented by the ROC (rank order centroid) method (Edwards and Barron, 1994) is easily applied because the only mandatory parameter is criteria preference order. Myllyvitta et al. (2012) highlight this advantage when they argue that current LCA practitioners are not familiar with MCDA methods and simple methods should therefore be prioritized. The weakness of this technique is the coarse approximation because weight calculation is based on the number of indicators. Points allocation provides more flexibility when defining weights as compared to the criteria preference order assignment and are more easily understood by decision-makers. Decision-maker expresses the importance of the indicators at each hierarchical level by assigning a value between 0 and 100. For each hierarchical level, the sum must be 100 (Roberts and Goodwin, 2002). In our case, we considered the points allocation for all MCDA methods to obtain the weights.

After establishing the weighting sets, we defined the other mandatory parameters for each method. For the AHP, the decision-maker makes a pairwise alternative comparison in each criterion considering the comparison assumption (semantic scale) proposed by Saaty (2005). This scale is qualitative and subjective. As such, it is difficult for the decision-maker to make the pairwise comparison. Considering this limitation, we translated the comparison assumption into an explicit scale, as provided at Box 3 . We considered gx (a) as the performance of product system " $a$ " in criterion $x$ and $\mathrm{gx}(\mathrm{b})$ as the performance of product system " $\mathrm{b}$ " in the same criterion $\mathrm{x}$. The decision-maker decides the interval of gx (a) - gx (b) where the comparison assumption (semantic scale) is representative.

For the Prométhée II outranking method, the mandatory parameters are the indifference and strict preference thresholds. To obtain these parameters, we defined a percentage scale in which decision-makers locate the thresholds associated with the strict preference and indifference 
for each criterion. The scale represents the difference (in percentage) of product system (pairwise) performances in a specific indicator.

Box 3. Translation of the qualitative scale into a cardinal scale for the AHP method

\begin{tabular}{|l|c|}
\hline \multicolumn{1}{|c|}{ Comparison assumption } & Interval \\
\hline Equal performance of the two alternatives & $g_{x}(a)-g_{x}(b)=0$ \\
\hline The performance of an alternative is slightly better than the other & $0.0>g_{x}(a)-g_{x}(b)>0.2$ \\
\hline The performance of an alternative is better than the other & $0.2>=g_{x}(a)-g_{x}(b)>0.4$ \\
\hline The performance of an alternative is much better than the other & $0.4>=g_{x}(a)-g_{x}(b)>0.6$ \\
\hline The performance of an alternative is categorically better than the other & $g_{x}(a)-g_{x}(b)>0.6$ \\
\hline
\end{tabular}

Considering the uncertain LCSA performances obtained by Monte Carlo simulation, we propagated the results into MCDA methods in order to generate the simulated rankings. The MCDA methods are implemented for the 1000 LCSA performance datasets in order to provide the rankings of the product systems following the same approach proposed by Marinoni (2005) and Hyde et al. (2003).

\subsubsection{Interpreting the stochastic results}

Rankings from MCDA methods are calculated from stochastic LCSA results. We analyzed the level of confidence of the rankings provided by MCDA methods. For each method, we calculated the probability that each product system is ranked as first, second, third or fourth. This information makes it possible to observe the robustness of the rankings provided by the different methods (counts of simulations where an alternative gets a specific ranking divided by total number of simulations). The level of confidence of the rankings proposed by the different MCDA methods is interpreted as the probability that a product system is ranked in a specific place.

\subsection{Case study illustrating the proposed approach}

We describe our approach through an illustrative case study on sustainable procurement that aims to rank a set of hypothetical biodiesel suppliers, represented by the product they deliver (biodiesel from soy produced in Argentina - BAS, biodiesel from palm oil produced in Malaysia BMP, biodiesel from soy produced in the United States - BUS and biodiesel from used oils produced in Québec - BUQ). The social and environmental life cycle performances are calculated for each product system considering the system boundaries provided in Figure 3. For the economic dimension, we considered the cost of the product at purchase.

For each product system, the analysis includes life cycle phases such raw materials supply (feedstock and vegetable oil production), biodiesel production, mix and stock and transportation activities. We did not include the use phase for the social dimension because all systems have the same performance because product use is carried out by the purchaser. The functional unit is 1 litre of biodiesel available for a vehicle in Québec for the social assessment and 1 litre of biodiesel used by a vehicle in Québec for the environmental assessment. It is important to remark that the focus of this paper is not providing a detailed LCSA study but propose a methodologyv able to integrate these results when supporting decision-making based on these results.

The four product systems are described in Box 4 and represent the biodiesel suppliers considered in the illustrative case study. 
Figure 3. Description of the life cycle phases and system boundaries for social and environmental assessments

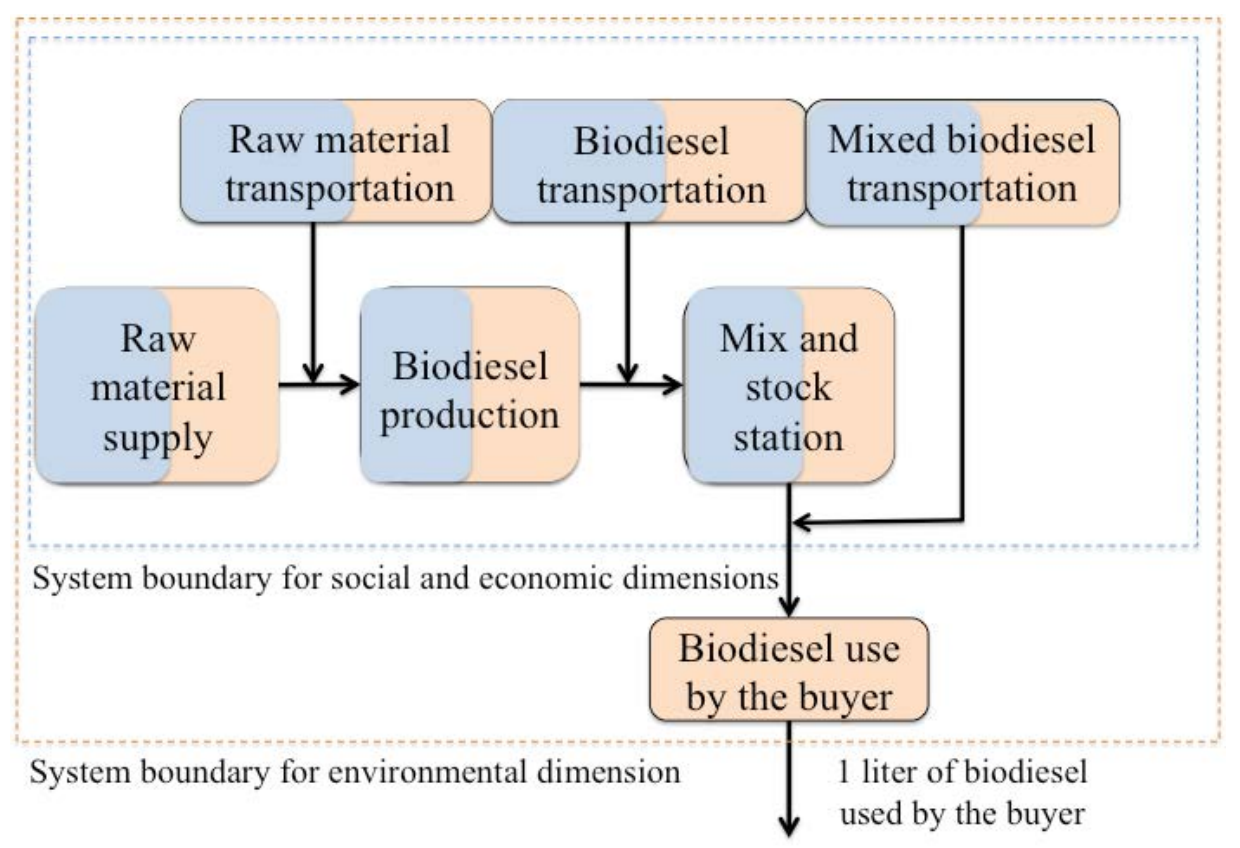

Box 4. Characteristics of the four product systems representing the hypothetical biodiesel suppliers in the illustrative case study.

\begin{tabular}{|c|c|}
\hline Product systems & Characteristics \\
\hline $\begin{array}{l}\text { Biodiesel from } \\
\text { Argentinian soy- } \\
\text { beans (BAS) }\end{array}$ & $\begin{array}{l}\text { - The vegetable oil is produced from soy produced in Argentina by a solvent process. } \\
\text { - The vegetable oil is transported by truck and ocean vessel. } \\
\text { - The biodiesel is produced in the United States. } \\
\text { - The biodiesel is transported by truck from the biodiesel factory to the mix and stock } \\
\text { station; mixed biodiesel is transported from the mix station to the consumer by truck. }\end{array}$ \\
\hline $\begin{array}{l}\text { Biodiesel from } \\
\text { Malaysian palm } \\
\text { (BMP) }\end{array}$ & $\begin{array}{l}\text { - The vegetable oil is produced from palm from Malaysia. } \\
\text { - The vegetable oil is transported by truck. } \\
\text { - The biodiesel is produced in Malaysia. } \\
\text { - The biodiesel is transported by ocean vessel from the biodiesel factory to the mix and stock } \\
\text { station; mixed biodiesel is transported from the mix station to the consumer by truck. }\end{array}$ \\
\hline $\begin{array}{l}\text { Biodiesel from } \\
\text { US soybeans } \\
\text { (BUS) }\end{array}$ & $\begin{array}{l}\text { - The vegetable oil is produced from soy produced in the US by a solvent process. } \\
\text { - The vegetable oil is transported by truck. } \\
\text { - The biodiesel is produced in the United States. } \\
\text { - The biodiesel is transported by truck from the biodiesel factory to the mix and stock } \\
\text { station; mixed biodiesel is transported from the mix station to the consumer by truck. }\end{array}$ \\
\hline $\begin{array}{l}\text { Biodiesel from } \\
\text { Québec used oil } \\
\text { (BUQ) }\end{array}$ & $\begin{array}{l}\text { Used oils from Québec is used as a raw material for biodiesel production. } \\
\text { - The biodiesel is transported by truck. } \\
\text { - The biodiesel is produced in Québec. } \\
\text { - The biodiesel is transported by truck from the biodiesel factory to mix and stock sta- } \\
\text { tion; mixed biodiesel is transported from the mix station to the consumer by truck. }\end{array}$ \\
\hline
\end{tabular}




\section{RESULTS}

The results are presented following the three phases proposed on Figure 2.

\subsection{Results Phase I: assessing product system performances}

Stochastic LCA results are presented in Figure 4 by probability density functions for each damage category in Impact 2002+ (human health, ecosystem quality, resources and climate change). The product system BUQ presents the best performances (lower impacts) in all damage categories. However, for the climate change indicator, there are overlaps with BMP. Other overlaps are observed between the different product systems to determine rankings 2 to 4 .

Stochastic social life cycle profiles for this illustrative case study were provided by Carmo et al. (2017), as shown in Figure 5. The higher the scores, the better the performances. Product system BUS presents the best results in the local community stakeholder dimension. Considering the society stakeholder dimension, there is clear overlap with the BAS product system. Finally, for the workers stakeholder dimension, BUS product system ranks first. Overlaps are also observed for other ranks in all three stakeholder dimensions.

Figure 4. Probability density function for the 4 hypothetical biodiesel suppliers (BAS, BMP, BUS and BUQ) -a) Human health, b) Resources, c) Climate change, d) Ecosystem quality-for the four damage scores in the Impact 2002+ method for 1000 simulations

a)

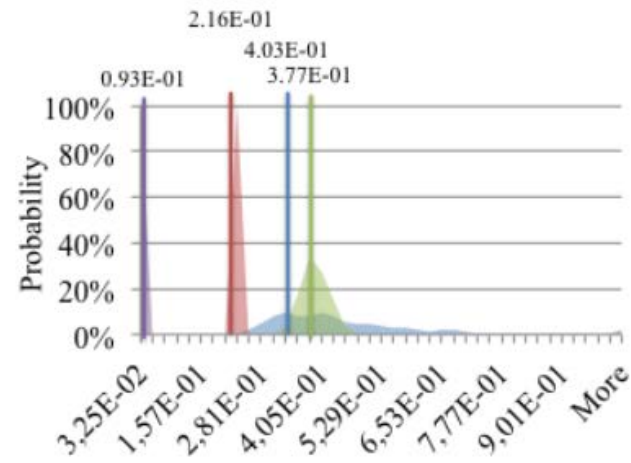

DALY

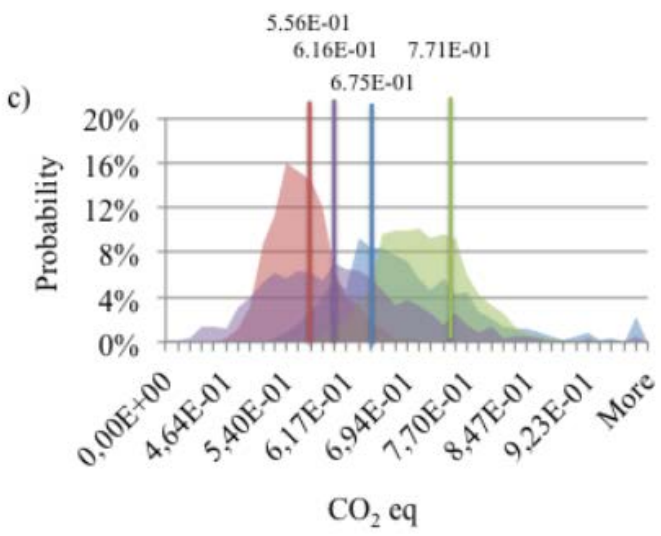

b)

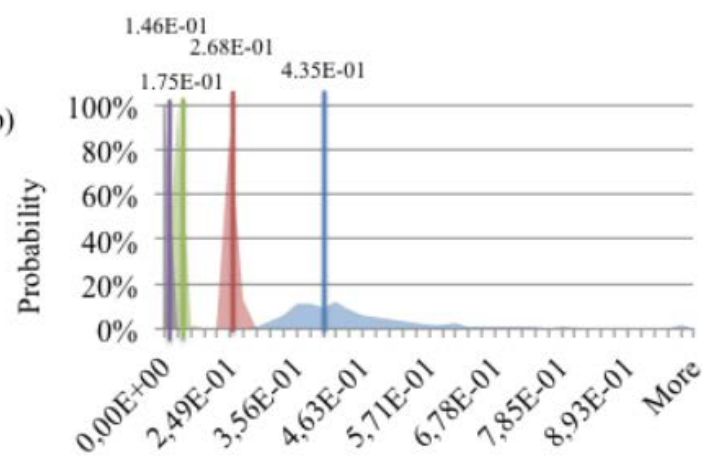

MJ

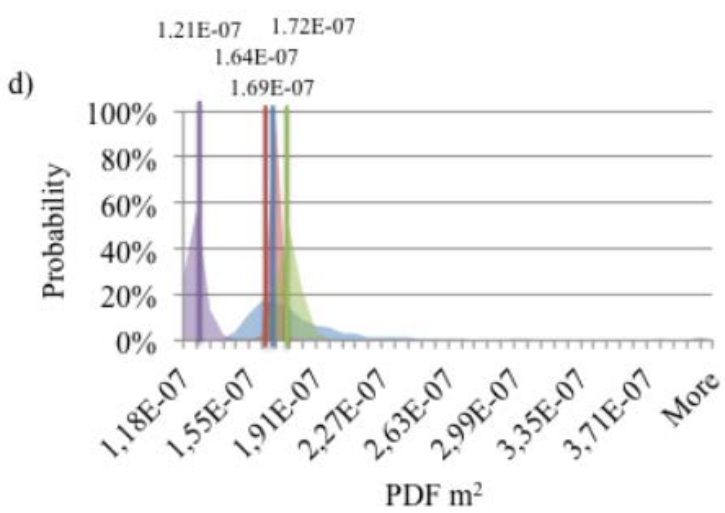

PDF $\mathrm{m}^{2}$

BUS - BUQ 
Figure 5. Social score probability density function (based on 1000 simulations) by stakeholder dimension for the four hypothetical biodiesel suppliers (BAS, BMP, BUS and BUQ): a) workers stakeholder dimension, b) society stakeholder dimension, c) local community stakeholder dimension. The higher the score, the better the social performance.

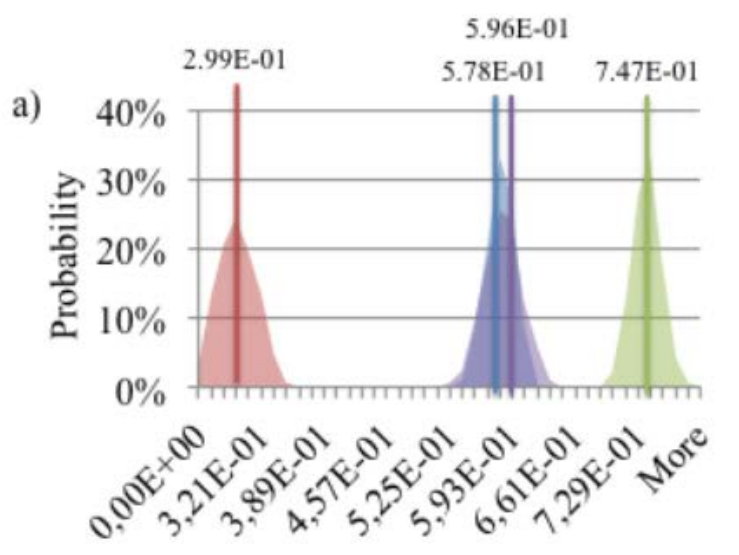

Social score for workers stakeholder dimension

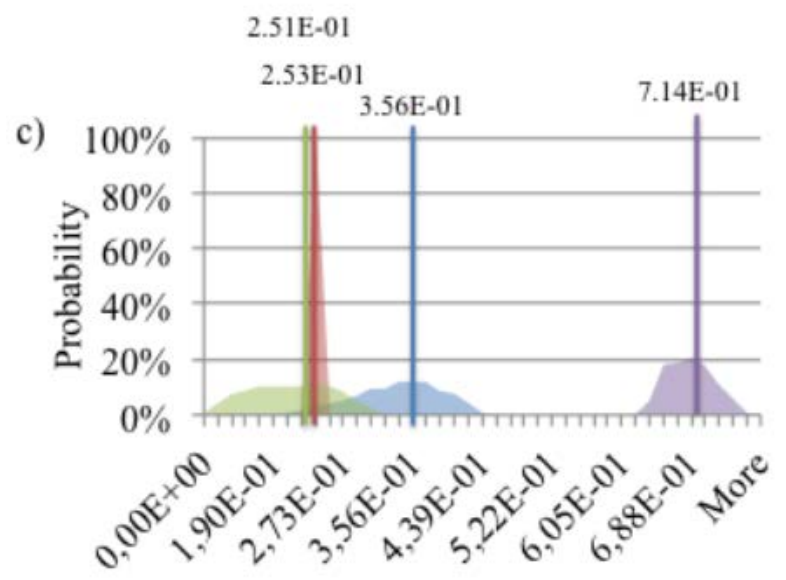

Social score for local community stakeholder dimension b)

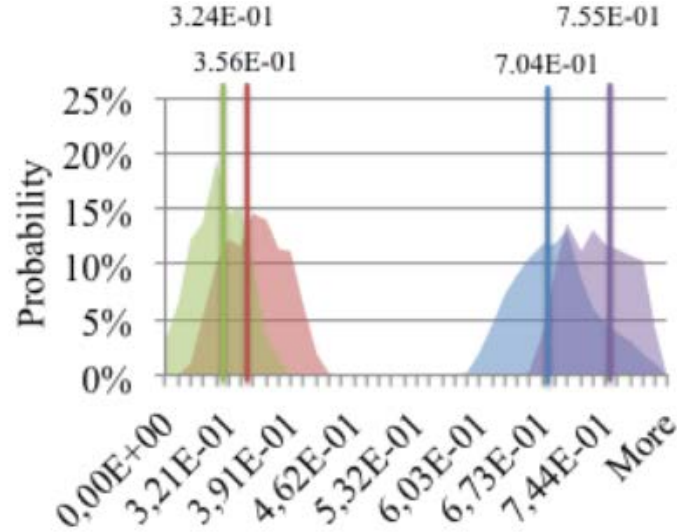

Social score for society stakeholder dimension 
Deterministic results for environmental and social profiles over the whole life cycle for the four hypothetical biodiesel product systems are provided as color lines in Figures 4 and 5.

For the economic dimension, we considered a hypothetical biodiesel purchase cost (deterministic value) for all simulations (Supplier $1-\$ 0.87 /$; Supplier $2-\$ 0.90 /$; Supplier $3-\$ 0.85 /$; Supplier $4-\$ 0.95 /$ I). The lower the cost, the better, as is the case for product system BUS. As such, we did not consider life cycle costing (LCC) in our analysis but it may be included in our framework as an economic performance indicator.

\subsection{Results Phase II: propagating LCSA uncertainty into MCDA methods}

MCDA methods were set up considering the value judgment of the decision-maker responsible for biodiesel procurement. Different mandatory parameters are necessary for each MCDA method with the exception of weighting factors (Table 1), which are common to all methods. For the outranking method, the required supplementary parameters are the thresholds presented in Table 2. They were established considering the value judgment of the decision-maker using the strategy illustrated in Figure 6. Finally, the AHP method requires defining the interval used to translate the qualitative comparison assumption into explicit quantitative scales, as presented in Box 3.

The rankings of the four biodiesel product systems generated by each MCDA method are presented in Box 5 (using deterministic LCSA performances). Three MCDA methods (weighted sum, AHP and TOPSIS) provided the same ranking (BUQ > BMP > BUS > BAS). Prométhée II inverted the second and third ranks (BUQ > BUS > BMP > BAS), highlighting the fact that different MCDA methods can lead to different ranking recommendations.

Table 1. Weighting factors used for all MCDA methods obtained by points' distribution technique

\begin{tabular}{|c|c|c|}
\hline \multicolumn{2}{|c|}{ Decision variables } & \multirow{2}{*}{ Weighting factors } \\
\hline Sustainability dimensions & Decision criteria & $8 \%$ \\
\hline \multirow{4}{*}{ Environmental } & Human Health & $4 \%$ \\
\cline { 2 - 3 } & Ecosystem quality & $16 \%$ \\
\cline { 2 - 3 } & Climate change & $12 \%$ \\
\cline { 2 - 3 } & Resources & $20 \%$ \\
\hline \multirow{3}{*}{ Social } & Workers & $8 \%$ \\
\hline & Society & $12 \%$ \\
\hline Economic & Local community & $20 \%$ \\
\cline { 2 - 3 } & Purchase cost & \multicolumn{2}{|c|}{8} \\
\hline
\end{tabular}


Table 2. Mandatory parameters of Prométhée II method obtained with the strategy illustrated in Figure 3

\begin{tabular}{|c|c|c|c|}
\hline \multicolumn{2}{|c|}{ Decision variables } & \multicolumn{2}{c|}{ Thresholds } \\
\hline Sustainability dimensions & Criteria & Indifference (q) & Preference (p) \\
\hline \multirow{3}{*}{ Social } & Workers & 0.1 & 0.4 \\
\cline { 2 - 4 } & Society & 0.2 & 0.4 \\
\cline { 2 - 4 } & Local community & 0.3 & 0.5 \\
\hline \multirow{3}{*}{ Environmental } & Human health & 0.2 & 0.4 \\
\cline { 2 - 4 } & Ecosystem quality & 0.1 & 0.4 \\
\cline { 2 - 4 } & Climate change & 0.2 & 0.4 \\
\cline { 2 - 4 } & Resources & 0.4 & 0.8 \\
\hline Economic & Price & 0.3 & 0.8 \\
\hline
\end{tabular}

Figure 6. Strategy used to obtain the thresholds from decision-makers for the Prométhée II method

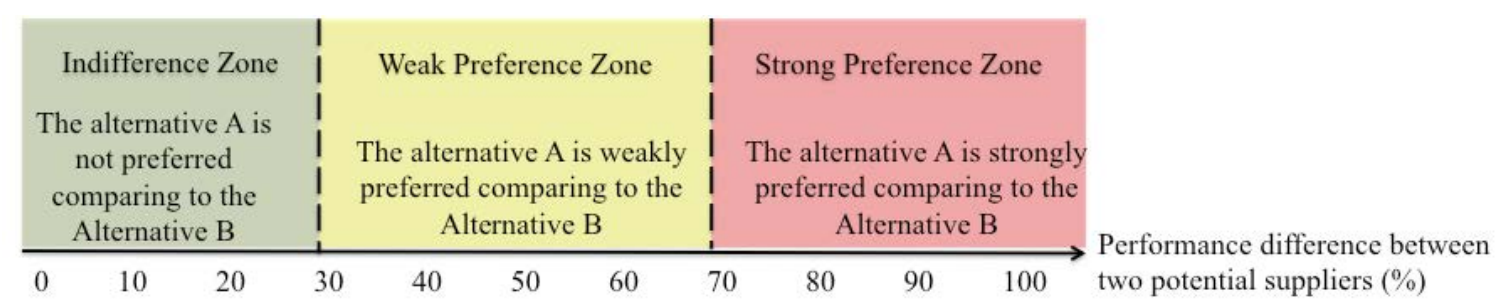

Box 5. Ranking of biodiesel product systems provided by MCDA methods using deterministic LCSA indicator profiles

\begin{tabular}{|c|c|c|c|c|}
\hline MCDA technique & 1st rank & 2nd rank & 3rd rank & 4th rank \\
\hline Weighted sum & BUQ & BMP & BUS & BAS \\
\hline AHP & BUQ & BMP & BUS & BAS \\
\hline TOPSIS & BUQ & BMP & BUS & BAS \\
\hline Prométhée II & BUQ & BUS & BMP & BAS \\
\hline
\end{tabular}


Figure 7 present the stochastic results of the four evaluated biodiesel product systems provided by each MCDA method through the respective probability density functions. The $y$-axis shows the probability and the $x$-axis the aggregated MCDA scores. The scales of the $x$-axis are different in each graphic because they are specific to each MCDA method. As such, we did not compare the absolute results among the different MCDA methods but only the rankings they provided.

The biodiesel represented by the BUQ product system appears to be the solution recommended by all MCDA methods with some nuances in the TOPSIS method, where the probability density functions of product system BMP in overlaps at ranking no.1. The results of Figure 7 do not make it possible to identify the rankings ( $2 \mathrm{nd}, 3 \mathrm{rd}$ and $4 \mathrm{th}$ ) of other product systems because there are several overlaps between the respective probability density functions. As such, further statistical analysis is needed to interpret these stochastic results.

Figure 7. Probability density functions for aggregated scores by MCDA method: a) weighted sum, b) analytic hierarchy process, c) TOPSIS, d) Prométhée II.

a)

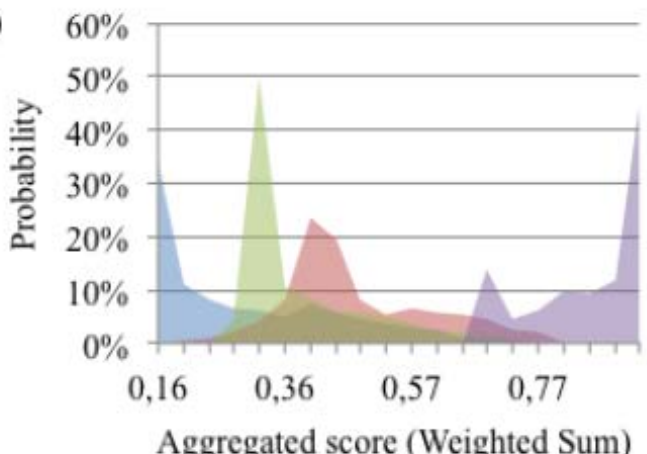

c)

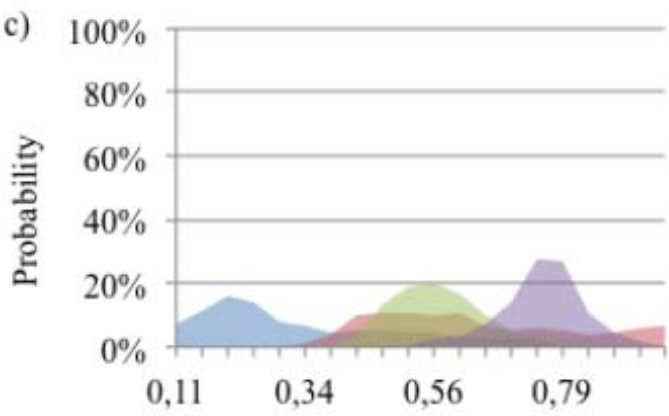

Aggregated score (TOPSIS) b)

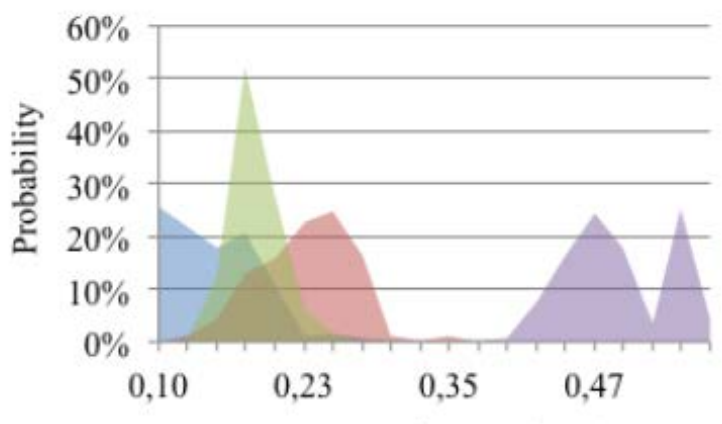

Aggregated score (AHP)

d)

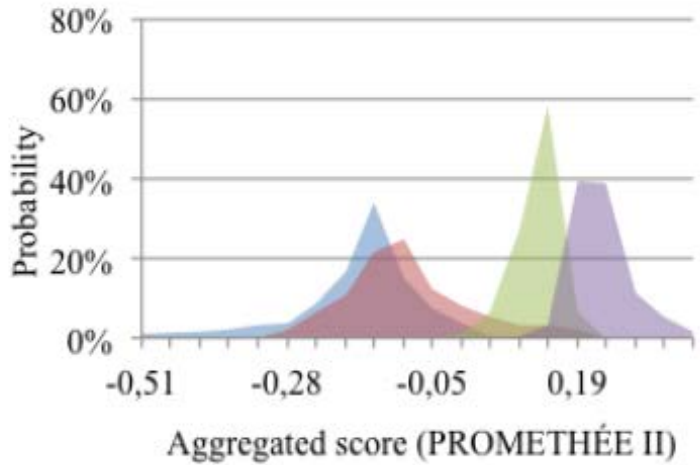

Legend: $\longrightarrow$ BAS - BMP $=$ BUS - BUQ 


\subsection{Phase III: interpreting stochastic results}

For each MCDA method, we calculated the probability that each product system is ranked in each possible rank. Box 6 reports the confidence level of each product system to be ranked 1st, 2nd, 3rd and 4th for each of the MCDA methods. All of the MCDA methods, with the exception of Prométhée II, converge, identifying the most probable ranking across biodiesel suppliers.

Product systems BUQ (purple), BMP (red), BUS (green) and BAS (blue) are ranked first, second, third and fourth by all MCDA methods with a probability of $68-100 \%, 38-84 \%, 61-75 \%$ and 62-77\%, respectively, except for Prométhée II, with which second and third places are inverted (BUS ranks second and BMP ranks third with a probability of $93 \%$ and $61 \%$, respectively).

The same rankings provided by the weighted sum, AHP, TOPSIS and Prométhée II MCDA methods were obtained for deterministic and stochastic LCSA results. However, different levels of confidence were obtained depending on the MCDA method. The determinist and stochastic results are the same for this illustrative case study because product system BUQ presents the best results for almost all criteria with small overlaps with other product systems. However, if there is a consistent overlapping among this product system with others, the results can be modified.

Box 6. Ranking confidence by MCDA method: a) weighted sum, b) analytic hierarchy process, c) TOPSIS, d) Prométhée II

a)

\begin{tabular}{|c|c|c|c|c|}
\hline WS & BAS & BMP & BUS & BUQ \\
\hline 1st & $0 \%$ & $0 \%$ & $0 \%$ & $100 \%$ \\
\hline 2nd & $25 \%$ & $69 \%$ & $6 \%$ & $0 \%$ \\
\hline 3rd & $13 \%$ & $26 \%$ & $61 \%$ & $0 \%$ \\
\hline 4th & $62 \%$ & $5 \%$ & $33 \%$ & $0 \%$ \\
\hline
\end{tabular}

c)

\begin{tabular}{|c|c|c|c|c|}
\hline Topsis & BAS & BMP & BUS & BUQ \\
\hline 1st & $1 \%$ & $30 \%$ & $1 \%$ & $68 \%$ \\
\hline 2nd & $12 \%$ & $38 \%$ & $22 \%$ & $28 \%$ \\
\hline 3rd & $11 \%$ & $11 \%$ & $75 \%$ & $3 \%$ \\
\hline 4th & $77 \%$ & $21 \%$ & $2 \%$ & $1 \%$ \\
\hline
\end{tabular}

b)

\begin{tabular}{|c|c|c|c|c|}
\hline AHP & BAS & BMP & BUS & BUQ \\
\hline 1st & $0 \%$ & $0 \%$ & $0 \%$ & $100 \%$ \\
\hline 2nd & $9 \%$ & $84 \%$ & $7 \%$ & $0 \%$ \\
\hline 3rd & $22 \%$ & $9 \%$ & $69 \%$ & $0 \%$ \\
\hline 4th & $70 \%$ & $7 \%$ & $24 \%$ & $0 \%$ \\
\hline
\end{tabular}

d)

\begin{tabular}{|c|c|c|c|c|}
\hline PRO & BAS & BMP & BUS & BUQ \\
\hline 1st & $0 \%$ & $0 \%$ & $2 \%$ & $98 \%$ \\
\hline 2nd & $0 \%$ & $5 \%$ & $93 \%$ & $2 \%$ \\
\hline 3rd & $34 \%$ & $61 \%$ & $5 \%$ & $0 \%$ \\
\hline 4th & $66 \%$ & $34 \%$ & $0 \%$ & $0 \%$ \\
\hline
\end{tabular}

\section{DISCUSSION}

Considering the results of Phase I, life cycle sustainability assessment performances presented by figures 4 and 5 , we conclude they are multi-dimensional and difficult to interpret. On one hand, they are comprehensive on the covered life cycle environmental and social issues, but on the other hand, they make complex the decision-making, because none of the alternatives presents the best performance across all indicators. The use of multiple criteria decision analysis (Phase II) provides a structured approach to account for value judgements though a multi-dimensional decision-making process aiming to identify the most appropriate solution (considering the research gap identified by Martín-Gamboa et al.,2017), as demonstrated by the results presented in figure 7 and Box 6. Figure 7 does not provides unidimensional, but stochastic results. BUQ shows up as the best compromise solution, but for some MCDA methods stochastic results still show some overlaps between the different biodiesel suppliers. As such, the results presented on box 6 (Phase III) translate stochastic results into a metric informing the decision maker about the robustness of the rankings generated by MCDA methods, i.e. the probability that a supplier ranks higher than the others. 
The complexity associated to the implementation of Phase II is associated to the elicitation process conducted in order to calibrate parameters of MCDA methods. This is especially true for the preference thresholds used by Prométhée II method, where the MCDA analyst had to support the decision-makers defining them during the calibration process. We also acknowledge that additional challenges may occur in a real situation in relationship to life cycle inventory data collection (Phase I). For instance, the company has limited or no influence over the upstream life cycle stages of the purchased fuels. Considering cases where the company has sufficient data about the product systems or is able to estimate the uncertainty of poor inventory information, this paper provides an approach to support decision-making, whilst being transparent on the influence of the stochastic uncertainty from LCA indicators on the final rank.

The answer generated by this novel approach on Phase III provides, in addition to the ranking of the evaluated solutions, an information about the confidence the decision maker can have in a given result (ranking of solutions). This is given under the form of a probability, e.g. solution " $\mathrm{A}$ " ranks first with $80 \%$ probability, similarly as weather forecast, i.e. tomorrow is raining with $60 \%$ of probability. It is important to remark that we considered decision-makers' value judgments represented by an average of their points of view. However, the use of a stochastic model to represent the value judgment variety can be included in future research.

Our approach was implemented with an Excel based prototype (available in the supporting information). LCA practitioners can use it to run their own simulations, considering a set of four product systems and the eight sustainability indicators defined in our approach.

Although the application of our approach is illustrated through to a live situation, where managers were interviewed to get their value judgment on a procurement process, the offered products does not represent real alternatives supplied by specific actors from the market. As such, we should refrain from deriving recommendations on the preference of any of the hypothetical biodiesel product systems analyzed here.

\section{CONCLUSION}

This research proposes a novel method able to combine uncertain life cycle sustainability performances with multiple criteria decision analysis (MCDA) approach to support decision-making. MCDA methods are able to enrich the interpretation phase of LCSA studies, providing support when using LCSA performances as input data into decision-making problems. However, most of reviewed studies are concentrated in combining determinist LCSA performances without analyzing the impact of uncertainty associated to these measures or the choice of MCDA method, limiting a practical use of LCSA in sustainability research, as remarked by Onat et al. (2016).

Hence, the fundamental methodological contributions of this paper are to (i) integrate LCSA uncertainty into decision-making processes through MCDA approach; (ii) provide a sensitivity analysis about the MCDA method choice, (iii) support decision-makers' preference choices through a transparent elicitation process and (iv) provide a practical decision-making platform that accounts simultaneously uncertain LCSA performances with stakeholders' value judgments.

The aim of our paper work is not to draw any specific conclusion on the preference of any of the considered biodiesel supply or to discuss their importance, but to illustrate the feasibility of such an approach addressing uncertainty of environmental, social and cost indicators in a MCDA in order to promote a practical use of LCSA in sustainability decision-making. The resulting stochastic preferences inform decision-makers on the robustness of the rankings provided by MCDA methods, overcoming the limitation of an excess of confidence of deterministic rankings. As result of our illus- 
trative case study, Quebec's biodiesel produced from used oils has come out being ranked first with a probability of more than $68 \%$ across all the simulations over the four applied MCDA methods.

As limitation and suggestion for future research, we must include LCC as economic performance and take into account decision-makers' value judgment variety. We did not conduct an uncertainty analysis on the weighting factors because the aim of the paper was to analyze how to propagate the LCSA uncertainty into decision-making processes by MCDA methods. However, our approach may be expanded to also address decision-maker uncertainty when defining weighting factors and other mandatory parameters of MCDA models. Similarly, it may be applied to all decision-related problems where uncertain social, environmental and economic life cycle performances are considered as decision criteria.

\section{ACKNOWLEDGEMENTS}

Financial support from Coordenação de Aperfeiçoamento de Pessoal de Nível Superior (Capes) is gratefully acknowledged. The authors would also like to thank the International Reference Centre for the Life Cycle of Products, Processes and Services (CIRAIG) and the Societe de transport de Montréal (STM), as well as Professor Bertrand Mareschal, Free University of Brussels, for his support with the MCDA approach.

\section{REFERENCES}

AMIRI M, NOSRATIAN N E, JAMSHIDI A AND KAZEMI A (2008) Developing a new electre method with interval data in multiple attribute decision making problems. J. Appl. Sci. 22: 4017-4028.

BALALI V, ZAHRAIE B AND ROOZBAHNI A (2014) Integration of Electre III and Promethee II decisionmaking methods with an interval approach: application in selection of appropriate structural systems. J. Comput. Civil Eng. 28(2): 297-314. doi: 10.1061/(ASCE)CP.1943-5487.0000254

BACHMANN T M (2013) Towards life cycle sustainability assessment: drawing on NEEDS project's total cost and multi-criteria decision analysis ranking methods. Int. J. Life Cycle Assess.18: 1698-1709. doi: 10.1007/s11367-012-0535-3

BENGTSON M (2001) Weighting in practice. J. Ind. Ecol. Ecology. 4(4): 47-60. doi: $10.1162 / 10881980052541945$

BRANS J-P AND MARESCHAL B (2005) Promethee methods. In Figueira J, Greco S and Ehrgott M (ed) Multiple Criteria Decision Analysis: State of Art, Surveys. Springer, Boston, pp 133-161.

CARMO BBT, MARGNI M, BAPTISTE P (2017) Addressing uncertain scoring and weighting factors in social life cycle assessment. Int J Life Cycle Assess. doi: 10.1007/s11367-017-1275

CARMO BBT, MARGNI M, BAPTISTE P (2017) Customized scoring and weighting approaches for quantifying and aggregating results in social life cycle impact assessment. Int J Life Cycle Assess. doi: 10.1007/s11367-017-1280-4

CHAI J, LIU J N K, NGAI E W T (2013) Application of decision-making techniques in supplier selection: a systematic review of literature. Expert Syst. Appl. 40: 3872-3885. doi: 10.1016/j. eswa.2012.12.040 
CLAVREUL J, GUYONNET D, TONINI D AND CHRISTENSEN T H (2013) Stochastic and epistemic uncertainty propagation in LCA. Int. J. Life Cycle Assess. 18:1393-1403. doi: 10.1007/s11367013-0572-6.

CUCURACHI S, SEAGER T P, PRADO V (2017) Normalization in comparative life cycle assessment to support environmental decision making. J. Ind. Ecol. Doi: 10.1111/jiec.12549

EDWARDS W AND BARRON F H (1994) SMARTS and SMARTER: improved simple methods for multiattribute utility measurement. Organizational Behavior and Human Decision Processes. 60 (3): 306-325. doi: 10.1006/obhd.1994.1087

FAGNEN, S, MÉNARD J F, BRODEUR C, BEAUDOIN D, LAMARCHE V, RÉVERET J P (2010) Analyse environnementale et socio-économique de l'utilisation de biodiesel en remplacement des produits pétroliers dans les autobus de la STM. Rapport d'analyse préliminaire CIRAIG, Montréal.

FINKBEINER M, SCHAU E M, LEHMANN A AND TRAVERSO M (2010) Towards life cycle sustainability assessment. Sustainability 2:3309-3322. doi: 10.3390/su2103309

GOUMAS M AND LYGEROU V (2000) An extension of the Promethee method for decision making in fuzzy environment: ranking of alternative energy exploitation projects. Eur. J. Oper. Res. 123:606-613. Doi: 10.1016/S0377-2217(99)00093-4

GUITOUNI A AND MARTEL J-M (1998) Tentative guidelines to help choosing an appropriate MCDA method. Eur. J. Oper. Res. 109:501-521. doi: 10.1016/S0377-2217(98)00073-3

HALOG A AND MANIK Y (2011) Advancing integrated systems modeling framework for life cycle sustainability assessment. Sustainability 3: 469-499. Doi: 10.3390/su3020469

HANANDEH A E AND EL-ZEIN (2010) The development and application of multi-criteria decisionmaking tool with consideration of uncertainty: The selection of a management strategy for the bio-degradable fraction in the municipal solid waste. Bioresour. Technol. 101: 555-561. doi: 10.1016/j.biortech.2009.08.048

HEIJUNGS R, HUPPES G AND GUINÉE J B (2010) Life cycle assessment and sustainability analysis of products, materials and technologies. Toward a scientific framework for sustainability life cycle analysis. Polym. Degrad. Stab. 95: 422-428. doi: 10.1016/j.polymdegradstab.2009.11.010

HENRIKSSON PJG, HEIJUNGS R, DAO HM, PHAN LT, DE SNOO GR, GUINÉE JB (2015) Product Carbon Footprints and Their Uncertainties in Comparative Decision Contexts. PLoS ONE 10(3): e0121221. doi:10.1371/journal.pone.0121221

HYDE K, MAIER H R AND COLBY C (2003) Incorporating uncertainty in Promethee MCDA method. J. Multi-Crit.Decis. Anal. 12:245-259. doi: 10.1002/mcda.361

JOLLIET, O, MARGNI M, CHARLES R, HUMBERT S, PAYET J, REBITZER G AND ROSENBAUM R (2003). IMPACT 2002+: A new life cycle impact assessment methodology. Int. J. Life Cycle Assess 8(6): 324-330. doi: 10.1007/BF02978505

KALBAR, P.P., BIRKVED, M., NYGAARD, S.E. AND HAUSCHILD, M (2017). Weighting and Aggregation in Life Cycle Assessment: Do Present Aggregated Single Scores Provide Correct Decision Support?. Journal of Industrial Ecology, 21(6), pp.1591-1600.

KELLER H, RETTENMAIER N, REINHARDT G A (2015) Integrated life cycle sustainability assessment - a practical approach. Appl. Energy 154:1072-1081. doi: 10.1016/j.apenergy.2015.01.095 
KLÖPFFER W AND CIROTH A (2011) Is LCC relevant in a sustainable assessment? Int. J. Life Cycle Assess. 16: 99-101. doi: 10.1007/s11367-011-0249-y

LAURIN L, AMOR B, BACHMANN T M, BARE J, KOFFLER C, GENEST S, PREISS P, PIERCE J, SATTERFIELD B AND VIGON B (2016) Life cycle assessment capacity roadmap (section 1): decision-making support using LCA. Int. J. Life Cycle Assess.21: 443-447. doi: 10.1007/s11367016-1031-y

LE TÉNO J F AND MARESCHAL B (1998) An interval version of Promethee for the comparison of building products' design with ill-defined data on environmental quality. Eur. J. Oper. Res. 109: 522-529. doi: 10.1016/S0377-2217(98)00074-5

PRADO-LOPEZ, V., SEAGER, T.P., CHESTER, M. ET AL. INT J LIFE CYCLE ASSESS (2014) 19: 405. https://doi.org/10.1007/s11367-013-0641-X

PRADO-LOPEZ, V. , WENDER, B. A., SEAGER, T. P., LAURIN, L. , CHESTER, M. AND ARSLAN, E. (2016), Tradeoff Evaluation Improves Comparative Life Cycle Assessment: A Photovoltaic Case Study. Journal of Industrial Ecology, 20: 710-718. doi:10.1111/jiec.12292

LORA E E S, PALACIO J C E, ROCHA M H, RENO M L G, VENTURINI O J AND OLMO O A (2011) Issues to consider, existing tools and constraints in biofuels sustainability assessments. Energy. 36:2097-2110. Doi: 10.1016/j.energy.2010.06.012

MARINONI O (2005) A stochastic special decision support system based on Promethee. International Journal of Geographical Information Science, 19(1): 51-68. doi: $10.1080 / 13658810412331280176$

MARTÍN-GAMBOA M, IRIBARREN D, GARCÍA-GUSANO, D AND DUFOUR J (2017) A review of life-cycle approaches coupled with data envelopment analysis within multi-criteria decision analysis for sustainability assessment of energy systems. J. Cleaner Prod. 164-174. doi: 10.1016/j.jclepro.2017.03.017

MOUSSEAU V (2003) Elicitation des préférences pour l'aide multicritère à la decision. Mémoire. Université Paris Dauphine.

MYLLYVIITA T, HOLMA A, ANTIKAINEN R, LÄHTINEN K AND LESKINEN P (2012) Assessing environmental impacts of biomass production chains - application of life cycle assessment (LCA) and multi-criteria decision analysis (MCDA). J. Cleaner Prod. 238-245. doi: 10.1016/j. jclepro.2012.01.019

NIE R, TIAN Z, WANG J, ZHANG H, WANG T (2018) Water security sustainability evaluation: Applying a multistage decision support framework in industrial region, J. Cleaner Prod. 196: 1681-1704. doi: 10.1016/j.jclepro.2018.06.144.

ONAT N C, KUCUKVAR M, TATARI O AND ZHENG Q P (2016) Combined application of multi-criteria optimization and life-cycle sustainability assessment for optimal distribution of alternarive passage cars in U. S. J. Cleaner Prod. 291-307. doi: 10.1016/j.jclepro.2015.09.021

POPE J, ANNANDALE D AND MORISSON-SAUNDERS A (2004) Conceptualising sustainability assessment. Environmental Impact Assessment Review. 24: 595-616. doi: 10.1016/j. eiar.2004.03.001

QIAO, D., SHEN, K., WANG, J. ET AL. J Ambient Intell Human Comput (2019). https://doi.org/10.1007/ s12652-019-01251-z 
QURESHI M N, KUMAR D AND KUMAR P (2007) Selection of potential 3PL services providers using Topsis with interval data. IEEE International Conference on Industrial Engineering and Engineering Management 1512-1516. doi: 10.1109/IEEM.2007.4419445

ROBERTS R AND GOODWIN P (2002) Weight approximations in multi-attribute decision models. J. Multi-Crit. Decis. Anal. 11: 291-303. Doi: 10.1002/mcda.320.

ROWLEY, H. V., G. M. PETERS, S. LUNDIE, AND S. J. MOORE. 2012. Aggregating sustainability indicators: Beyond the weighted sum. Journal of Environmental Management 111: 24-33.

ROY B (2005) Paradigms and Challenges. In Figueira J, Greco S and Ehrgott M (ed) Multiple Criteria Decision Analysis: State of Art, Surveys. Springer, Boston, pp 4-24.

SAATY T L (2005) The analytic hierarchy and analytic network processes for the measurement of intangible criteria and for decision-making. In Figueira J, Greco S and Ehrgott M (ed) Multiple Criteria Decision Analysis: State of Art, Surveys. Springer, Boston, pp 344-407.

SANCHEZ-RAMIREZ PK, PETTI L, HABERLAND NT, UGAYA CML (2014) Subcategory assessment method for social life cycle assessment. Part 1: methodological framework. Int J Life Cycle Assess 19: 1515-1523

SAYYDI M AND MAKUI A (2012) A new view to uncertainty in Electre III method by introducing interval numbers. Decision Science Letters 1:33-38. Doi: 10.5267/j.dsl.2012.06.002

SHÄRLIG A (1985) Décider sur plusieurs critères: panorama de l'aide à la décision multicritère. Presses polytechniques et universitaires romandes, Lausanne, Suisse.

SOHN, J., KALBAR, P., \& BIRKVED, M. (2017). Life cycle based dynamic assessment coupled with multiple criteria decision analysis: A case study of determining an optimal building insulation level. Journal of Cleaner Production, 162, 449-457. DOI: 10.1016/j.jclepro.2017.06.058

TRAVERSO M, FINKBEINER M, JORGENSEN A AND SCHNEIDER L (2012) Life cycle sustainability dashboard. J. Ind. Ecol. 16(5): 680-688. doi: 10.1111/j.1530-9290.2012.00497.x

UNITED NATIONS ENVIRONNEMENT PROGRAM - UNEP (2013) The methodological sheets for sub-categories in social life cycle assessment (SLCA). Life Cycle Initiative. http://Icinitiative. unep.fr/. Accessed 20 June 2015.

VAHDANI B, JABBARI A H K, ROSHNAEI V, ZANDIEH M (2010) Extension of electre method for decision-making problems with interval weights and data. Int. J. Manuf. Technol. Manage. 50:793-800. Doi: 10.1007/s00170-010-2537-2

VINYES, E., OLIVER-SOLÀ, J., UGAYA, C., RIERADEVALL, J. ET GASOL, C. M. (2013) Application of LCSA to used cooking oil waste management. Int. J. Life Cycle Assess. 18: 445-455. doi: $10.1007 / \mathrm{s} 11367-012-0482-z$

WERNET G, BAUER C. STEUBING B, REINHARD J., MORENO-RUIZ E, AND WEIDEMA B (2016). The ecoinvent database version 3 (part I): overview and methodology. Int. J. Life Cycle Assess. 21(9), pp.1218-1230. doi: 10.1007/s11367-016-1087-8.

YANARELLA E J, LEVINE R S AND LANCASTER R W (2009) Sustainability. The Journal of Record, 2(5) pp. 296-302.

YANG Z L AND WANG B J (2011) Approximate Topsis for vessel selection under uncertain environment. Expert Syst. Appl. 38: 14523-14534. doi: 10.1016/j.eswa.2011.05.032 
ZHANG K AND ACHARI G (2010) Uncertainty propagation in environmental decision making using random sets. Procedia Environ. Sci. 2: 576-584. Doi: 10.1016/j.proenv.2010.10.063

ZAMAGNI A, PESONEN H-L AND SWARR T (2013) From LCA to life cycle sustainability assessment: concept, practice and future directions. Int. J. Life Cycle Assess. 18: 1637-1641. doi: 10.1007/ s11367-013-0648-3. 


\section{AUTHORS}

\section{Breno Barros Telles do Carmo}

Professor of Federal University of the Semi-Arid Region (UFERSA), Brazil. Ph.D in Industrial Engineering from École Polytechnique de Montréal, Université de Montréal, Canada.

E-mail: brenobarros@ufersa.edu.br

ORCID: http://orcid.org/0000-0002-7506-7037

\section{Manuele Margni}

Professor of École Polytechnique de Montréal, Canada. Ph.D from École Polytechnique Fédérale de Lausanne, Switzerland. E-mail: manuele.margni@polymtl.ca

ORCID: https://orcid.org/0000-0002-2475-0768

\section{Pierre Baptiste}

Professor of École Polytechnique de Montréal, Canada. Ph.D from Université Lyon I, France.

E-mail: pierre.baptiste@polymtl.ca

ORCID: https://orcid.org/0000-0002-0471-6706

\section{Contribution of authors.}

\begin{tabular}{|l|c|c|c|}
\hline \multicolumn{1}{|c|}{ Contribution } & [Author 1] & [Author 2] & [Author 3] \\
\hline $\begin{array}{l}\text { 1. Definition of research problem } \\
\text { 2. Development of hypotheses or research questions } \\
\text { (empirical studies) }\end{array}$ & $\mathrm{V}$ & $\mathrm{V}$ & $\mathrm{V}$ \\
\hline $\begin{array}{l}\text { 3. Development of theoretical propositions } \\
\text { (theoretical work) }\end{array}$ & $\mathrm{V}$ & $\mathrm{V}$ & \\
\hline 4. Theoretical foundation / Literature review & $\mathrm{V}$ & & \\
\hline 5. Definition of methodological procedures & $\mathrm{V}$ & $\mathrm{V}$ & \\
\hline 6. Data collection & $\mathrm{V}$ & & $\mathrm{V}$ \\
\hline 7. Statistical analysis & $\mathrm{V}$ & & \\
\hline 8. Analysis and interpretation of data & $\mathrm{V}$ & $\mathrm{V}$ & $\mathrm{V}$ \\
\hline 9. Critical revision of the manuscript & $\mathrm{V}$ & $\mathrm{V}$ & $\mathrm{V}$ \\
\hline 10. Manuscript writing & $\mathrm{V}$ & $\mathrm{V}$ & $\mathrm{V}$ \\
\hline 11. Other (please specify) & & & \\
\hline
\end{tabular}

